ISSN 1816-6075 (Print), 1818-0523 (Online)

Journal of System and Management Sciences

Vol. 9 (2019) No. 3, pp. 1-25

DOI:10.33168/JSMS.2019.0301

\title{
Environmental Risk and Innovation in Supply Chain: Analysis of Influence of Supply Chain Agility
}

\author{
Reza Ehtesham Rasi, Danial Hatami \\ Department of Industrial Management, Qazvin Branch, Islamic Azad University, \\ Qazvin, Iran
}

\begin{abstract}
Today, the survival of corporations is directly associated with the power of corporations to reinforce competitiveness that the supply chain agility plays a crucial role during this regard. This study was conducted by the aim of determinant the impact of provider innovation and environmental uncertainty on supply chain agility with the mediating role of data sharing, strategic resourcing, offer chain orientation and market orientation in elements suppliers of Sazeh Gostar Saipa Company (SGSC). This is often an applied analysis that is descriptive survey in terms of technique, and therefore the statistical population consisted of 515 managers of elements suppliers of SGSC. The Cochran formula was employed by SPSS twenty-two package to work out the quantity of samples, wherever of 228 managers participated during this study entirely. Normal questionnaires were administered to them. Correlation check results showed that there's a major positive relationship between the analysis variables $(\mathrm{p}<0.01)$. Also, the results of structural equation modeling by LISREL9 showed that the model given during this study features an appropriate fit and therefore the set of things that influenced the supply chain agility during this model will make a case for ninety eight of the changes in supply chain agility $(\mathrm{R} 2=0.98)$.
\end{abstract}

Keywords: innovation, uncertainty, agility, information, strategic, supply chain orientation.

\section{Introduction}

Organizations have perpetually been baby-faced with challenges of environmental changes and currently they're extensively faced with environmental uncertainty, together with the size of competition and market behavior.). During this regard, Jaffar Nezhad and Darvish (2009) argue that the amendment and turbulence area unit thought of as integral components of business in several markets supply chain. Managers need to settle for uncertainty and, at identical time, organize and develop an acceptable strategy to coordinate supply and demand with affordable cost. 
In addition, it's evident that no company has all the mandatory resources to place any chance on the market. Therefore, to realize a competitive come on the world market, corporations should work with suppliers and customers to uniform synced operations and succeed level of agility on the far side the reach of exclusive corporations, that normally has been sent to the chain of agility (Abdi and Abumusa, 2017).On the opposite hand, over the past decade, corporations have faced the growing international competition because of business agreements, the removal of business barriers and exaggerated access to international markets' customers (Tizro et al., 2011). Corporations have additionally faced fast technological changes, the growing uncertainty and market dynamism, reducing product lifecycles, and also the growing market segmentation within the international atmosphere. Therefore, the organization's ability to quickly adapt to environmental changes and market conditions is a necessary part of their survival (Agarwal et al., 2007; Van Hoek, 2011). In such a scenario, the importance and necessity of implementation of the agile offer chain becomes additional evident, as a result of such a series will react quickly and effectively to plug changes (Power, 2011; Qrunfleh, \& Tarafdar, 2013). On the opposite hand, supply chain management has been known united of the key factors within the competitiveness and success of organizations and also the pursuit of agility within the offer chain as an artificial thought in offer chain management has currently attracted the eye of the many managers and specialists and researchers area unit seeking to produce new dimensions of this rising thought (Kazazi \& Sohrabi, 2010). offer Chain Management (SCM) manages controls and coordinates supply and demand designing, making ready materials, manufacturing and designing merchandise, dominant the stock, distributing, delivering and serving) Fakhrzad et al.,2018). In general, today's review of organizations shows that past approaches and solutions have lost their talents to deal with structure challenges and up to date external environments (Mandal, 2016; Moniruzzaman et al., 2016). Hence, new approaches area unit required wherever agility is among them (Chegeni et al., 2016). within the in the meantime, the importance of agile offer chain is more increased, as a result of such a series will respond quickly and effectively to plug changes (Gebrekidans, 2016). Today, the utilization of an agile supply chain is crucial to realize success and make a competitive advantage (Kim \& Chai, 2017). at studies have shown that the advance of offer chain agility will evoke higher monetary performance (Gligor, 2013) and is very vital to require advantage of this to boost overall business performance, particularly for organizations with a high order level (Um, 2016).

Competitiveness could be a topic that has perpetually dedicated an enormous a part of organizations focus to itself particularly among producing companies (Fernando, 2017). The survival of corporations during this turbulent world is directly associated with the flexibility of corporations to reinforce their competitive power, that within the in the meantime, the availability chain agility role (Fernando, 
2017; Zutshi et al., 2015;). utilizing Associate in Nursing agile supply chain, whereas facilitating the delivery of products from producer to client, provides production conditions to makers in such how that corporations deal with a minimum price of stopping production or buy in of raw materials (Seyedhoseini et al., 2010; Sukati et al., 2012).Accordingly, it are often argued that its aggressiveness and growing trend have junction rectifier producing corporations to use numerous ways and techniques to with success contend, and also the supply chain is one in every of the paradigms of production that has been notably vital during this regard, however the way to succeed it's perpetually been a difficult issue for corporations (Khan \& Pillania, 2008).There is an issue among researchers in determination this downside, and it can't be clearly declared what the foremost vital and appropriate variables area unit to realize an organization's agility (Mandal, 2006). The quality of the subject is additional evident once the studies conducted during this field show completely different variables to producing companies' managers, whereas the given models don't seem to be within the sort of a developed model; (Moniruzzaman et al., 2016; Gebrekidans, 2016). Experimental studies show that provider innovation will have a right away impact on the corporations' offer chain lightsomeness whosefinal outcome are often pursued within the competitive advantage of companies. What justifies \{this is|this is often|this will be\} the utilization of suppliers from innovations that discourage different competitors at high speed within the field of competition and producing corporations can additional with confidence arrange their productions and distributions (Chen , 2015). However, the dearth of studies during this field has created the impact of supplier's innovation on the agility of the organization obscure and obscure, and it's not clear what intermediate variables i.e. quality and competitive will knock off facilitating this relation (Kim \& Chai, 2017).In the in the meantime, surveys show that the data sharing of corporations with a supplier are often vital in reference to the state of production and its programing system \&\#40;Kocabasoglu \& Suresh, 2006\&\#41; Obviously, sharing info will justify a mediating role within the relationship between the supplier's innovation and its adaptation to the availability chain agility (Kim \& Chai, 2017).

On the opposite hand, listening to a different thought like strategic resources is incredibly vital in these relationships. It encourages the manufacturers' strategy to be in line with the supplier's strategy that successively ends up in higher collaboration with dynamical business environments. Strategic resources comprises four main dimensions: strategic buying, internal integration, info sharing and supplier development (Chiang et al., 2012). Proof during this section additionally confirms that focus to the strategic resources specializing in strategic purchases will play a very important role within the relationship between suppliers' innovation and also the supply chain agility (Kim \& Chai, 2017). However, another principle of supply chain agility has been neglected: environmental uncertainty. This makes it 
troublesome for corporations to properly have strategic management with their suppliers and up to date proof suggests that the environmental uncertainty that corporations face results on 2 issues: supply chain orientation and market orientation and these 2 vital ones can effect on the availability chain agility. there's additionally an absence of studies during this field (Gligor et al., 2016). The proof from the 2 recent studies (Kim \& Chai, 2017; Gligor et al., 2016) clearly confirms that corporations ought to have special attention to basic contexts, environmental uncertainty and provider innovation, in supply chain agility each of that have an effect on the availability chain agility through intermediator variables. Within the real supply chain atmosphere, retailers ought to defend themselves from uncertainties in demand and provide. Demand and provide chain designing is incredibly complicated (Harbi et al, 2018).

However, the dearth of examination of the 2 models given within the sort of a comprehensive and developed model makes it not possible to properly confirm that of the 2 principles named in recent studies (i.e., uncertainty and provider innovation) has additional result on supply chain agility. consequently, within the gift study, the researchers attempt to answer the question what result supply innovation and environmental uncertainty wear supply chain agility and what the roles of mediating area unit in info sharing, strategic resources, supply chain orientation and market orientation.

In the following, the theoretical framework is given to review and compile the analysis hypothesis. Next, the analysis technique and findings are given and finally, the discussion and comparison of the findings are done.

\section{Theoretical Framework}

\subsection{Uncertainty and the supply chain agility}

Environmental uncertainty refers to inability to determine probabilities with a degree of certainty about how the environmental factors effect on the success or failure of the decision-making unit in supply chain. Environmental uncertainty also refers to a variety of external forces that an organization must interact with (Ajibolade et al, 2010).In many markets, changes and turbulence have become an integral part of business. In this way, supply chain managers must accept uncertainty and, at the same time, organize and develop a suitable strategy to coordinate supply and demand at an acceptable cost (Jafarnezhad \& Darvish, 2009). Environmental uncertainty is a key variable that affects organizational structure. The relationship of environmental uncertainty for each of the four characteristics (i.e., centralization, formalism, complexity, and integrity) affects the organizational structure (Gordon \& Narayanan, 2007).Social factors changes that emerge in order to protect the environment, labor expectations, and legal pressures are necessary to maintain a company and attract enough customers to generate positive cash flow 
and profitability. An environment of uncertainty requires rapid response to changes or so-called agility. The needs of organizations that prefer to respond more quickly to the needs of their customers, the changing environment of competition and the increasing complexity of the environment have led to the emergence of agility (Gligor et al, 2013). Todays, firms are in a global environment, which is surrounded by complexity and uncertainty. This uncertainty has a profound effect on the company's activities, especially the supply chain. On the other hand, accelerating the various changes and tight competition between companies reveal the need to accelerate the company's operations and its flexibility more than ever before. Agility of the supply chain is one of the most important factors in achieving the company agility and can meet the strategic goals of the company in today's competitive world (Nasrollahi et al., 1395). Accordingly, the first hypothesis was developed as follows:

H1: Uncertainty affects supply chain agility.

\subsection{Uncertainty and supply chain orientation}

The orientation of the provision chain links the upstream processes (the initial suppliers, as well as all processes concerned in getting and transportation) to downstream processes (including all processes concerned in distributing and delivering product to final customers) (Esper et al.,2010). Build up a series and making an attempt to extend the advantages of the whole supply chain are essential to survival and success of current markets. Makers, suppliers, distributors, warehouses, retailers and customers have tried insuring themselves in international markets through building a network of organizations and activities within the kind of a supply chain. That is, organizations work along to realize common goals, and that they have a best supply chain orientation, and also the advantages don't seem to be shared among the members of the chain in order that every element of the chain just seeks to extend its profit. Will be achieved once the members of the chain can build the mandatory coordination. During this case, the sole hypothesis for chain success is provided, however it's not enough to ensure it. as a result of this markets are speedily developing and every chain has robust competitors WHO provide a lot of choices to customers, , every chain has many choices to decide on its members and facilities; it conjointly wants the foremost applicable choice to succeed and to possess a lot of competitive benefits over its competitors (Adabi, 2014). Todays, several executives apprehend that actions taken by one amongst the chain members will have an effect on the profit of all different chain elements. Firms typically contend with different supply chains a region of supply chain and don't contend with their supply chain elements. Prices of poor coordination between elements are often extraordinarily high. During this regard, the necessary issue of characteristic and managing the risks within the cycle can't be unheeded. Basically, because of the character of risk, risk management must produce a comprehensive and holistic perspective on structure advancement and activities. To guide and management all 
steps concerned in making, shaping, documenting and dominant risks within the chain, supply chain orientation should be familiarized towards making price for patrons and firms as a region of supply chain typically contend with different supply chains and don't contend with their supply chain elements (Naini et al., 2011).The orientation of the provision chain elements will have an effect on the chain lightness. Therefore, an agile supply chain is in a position to adequately answer changes within the work. Agility within the offer chain is that the ability of a supply chain to reply quickly to plug changes and client wants (Gligor et al., 2016). Consequently, the second hypothesis was developed as follows:

H2: Uncertainty affects supply chain orientation.

\subsection{Uncertainty and the company market orientation}

Market orientation could be a quite behavioral norm that extends across the organization and is alert to current and future desires of the market and client through innovation. Market-oriented firms have a competitive advantage in responding quickly to plug and client needs; they conjointly act effectively in response to plug opportunities and threats (Kumar et al., 2011). Also, the marketoriented approach is to be told regarding the market and use it in selling actions. The company's market-orientation is taken into account as a philosophical approach to the selling of shoppers, competitors and plenty of factors touching on the wants and preferences of shoppers (Murray et al., 2011). In line with Narver and isopod (2000), the atmosphere during which fashionable firms' area unit settled is associate atmosphere of quality and uncertainty. Customers area unit more and more pushing firms to induce higher merchandise, services organizations so as to realize competitive advantage and success during this turbulent atmosphere should place their customers and therefore their desires and needs at the middle of their business and a spotlight as a result of these days business atmosphere is very influenced by the competition between companies and therefore the speedy technological amendments and the continuous change within the demands and wishes of shoppers. The market-oriented approach contributes to the important implementation of this idea. Therefore, it may be aforesaid that market orientation lies within the construct of selling. Market orientation is concerned as a result of with increasing competition among makers, uncertainty rises, and therefore the market orientation puts customers at the middle of attention and seeks to make a superior value for them. The market orientation considers to produce a superior value for patrons, competitors and their strengths and weaknesses still as inter-tasking coordination. Market-oriented firms have a competitive advantage in responding quickly to the wants of the market and customers in today's turbulent market. Consequently, the third hypothesis is as follows:

H3: Uncertainty affects the company's market orientation.

\subsection{Supplier innovation and supply chain agility}


Innovation may be a common method even in established sectors and creates opportunities for organizations to seize new markets and eliminate stagnation and downswing and threaten existing businesses (Racela, 2014). The globe around and later on the management practices square measure dynamic and to reach a unique world, there ought to be a unique management. agility is one amongst the vital factors that permits the manager to agitate changes additional properly, quicker and effectively, utilize the potential opportunities created by the amendment within the best means, work to enhance the organization and to satisfy the goals and future desires of the organization and conjointly introduce high-quality product and services in an exceedingly comparatively short amount of your time, produce competition and a few reasonably market differentiation from a spread of aspects like value, quality, delivery time, flexibility, fast response. During this regard, innovative suppliers will have an impression on agility (Golavar, 1394). The agile supply chain embraces a collection of corporations that square measure become independent from one another and mutualism at a similar time. During this means, corporations to surpass competitors should be united with suppliers to realize tier of agility within the provide chain. During this context, provider innovation plays a vital role within the agile supply chain in order that selecting associate innovative supplier generally becomes a significant issue for the organization (Kim and Chai, 2017). Consequently, the fourth hypothesis is as follows:

H4: supplier innovation affects supply chain agility.

\subsection{Supplier innovation and data sharing}

Sharing data is that the most elementary style of coordination in provide chains (Kazemzadeh et al., 2013). Data sharing is delineated as "foundation", "core element", "center of nervous system" and "main need" of coordination. Therefore, chain partners ought to share their data to facilitate supply chain coordination (Zhang et al., 2009). Data technology capabilities like core competencies belong to sharing data. Like the developments in data technology (such because the web, computer network and Extranet), a lot of the dealings prices related to knowledge transfer are reduced and an oversized quantity of knowledge is sharing at the proper time and with a fascinating quality. Also, only if the supplier plays a very important role within the organization's supply chain, supplier innovation will facilitate to get the resources required for flourishing implementation of knowledge sharing and also the creation of a confirmative democratic culture (Frazier et al., 2009). In organizations that get pleasure from supplier innovation and data sharing between the provider and alternative elements of the provision, semi-permanent relationships with the chain partners square measure inspired through social norms and trust rather than legal and inflexible contracts. In such organizations, sharing are going to be of nice importance as a mechanism to form coordination and cooperation with supply chain partners (Prajogo and Olhager, 2012). Consequently, the fifth hypothesis is as follows: 
H5: supplier innovation affects data sharing.

\subsection{Supplier innovation and strategic resources}

Strategic sources talk over with the company's attention to the supply of raw materials and different necessities that area unit thought of as vital and strategic problems. Therefore, it's spoken as strategic resources, so the corporate while not taking note to them, they will suffer from much injury, and if these vital and strategic resources area unit timely delivered, the corporate can have higher ability and performance to satisfy the longer term client desires (Kim \& Chai, 2017). The tendency to initiate within the supplier affects the method of buying between patrons and suppliers. Innovation in product and processes affects higher cognitive process concerning strategic provide chain resources (Oke et al., 2013). supplier innovation pays careful attention to the supply of initial resources; thus, the acquisition and procural strategy is of nice importance and cases like timely delivery of raw materials, reducing the retardation of speedy technological changes, adequate material transportation, adequate inventory and price savings area unit the characteristics of supplier innovation (Kibbeling et al, 2013). In purchases with strategic importance, raw materials and components area unit purchased once needed at varied stages of production. This fashion of buying and managing inventories permits the materials to be purchased on time and used at an equivalent time within the production method, leading to important savings in costs because of lower inventory levels. Given the increasing aggressiveness of today's firms and timely production, the presence of suppliers which will facilitate firms during this scenario is crucial (Myreen, 2010). Consequently, the sixth hypothesis is as follows:

H6: supplier innovation affects strategic resources.

\subsection{Information sharing and supply chain agility}

Establishing a shared system between the corporate and suppliers, sharing info between completely different units, business and electronic acquisition development within the supply chain, and exploitation artificial intelligence in decision making area unit the capabilities of knowledge technology to realize agility (Kazazi and Sohrabi, 2010). info technology tries to save lots of the organization's time, cash and agility by making direct channels of receiving info between the sales centers and also the headquarters, establishing an electronic portal to get info about client orders and dominant daily sales, creating affiliation between the supply department and also the development department, coordinating between sales and operation departments, and most significantly sharing the data (Huanga et al., 2012). Consequently, the seventh hypothesis is as follows:

H7: info sharing affects the availability chain agility.

\subsection{Strategic resources and supply chain agility}

One of the areas wherever managers have centered thereon a lot of is buying and 
resourcing management. Within the last decade, buying management within the supply chain has been a challenge for major firms, and achieving a world competitive level in supply has become a serious would like. Therefore, firms should rigorously review their buying strategy to hide environmental turbulence. Additionally, firms should listen to the very fact that selecting a method can have an effect on market competition (Monczka et al., 2015). Buying selections have an effect on the character and scope of provide chains. Managers who build these selections will form their value, risk, and performance structures (Wang, 2010). With the growing importance of supply chain nimbleness, buying patterns have a central role that may boost an organization from a brief vendee to a strategic partner. Having a buying strategy also can be effective in increasing the provision management capabilities. With relation to the importance and enlargement of supply chain nimbleness in organizations, the importance of targeting the purchases has conjointly doubled. The impact of up the performance of those 2 sections is visible on the performance of the organization during a style of ways that, like reducing inventory, increasing sales, decreasing client waiting time and lots of different things that ultimately result in improve company performance (Baghebani, 2011). Consequently, the eighth hypothesis is as follows:

H8: Strategic resources have an effect on the provision chain agility.

\subsection{Supply chain orientation and supply chain agility}

Companies ought to pay due attention to supply chain orientation so as to manage the connection with the most provider, as a result of this can result in produce relationship management with the most supplier and additionally firms gain higher performance outcomes and expand the supply chain read by making a supply chain orientation (Mehrabani \& Hasanzadeh, 2015). To guide and management all the steps concerned in making, shaping, documenting and dominant the chance within the chain, supply chain orientation should be orientated towards making worth for purchasers (Naini et al., 2011). Supply chain orientation will improve the strategic resources and fight of the corporate and presumably improves agility of the company's offer chain. (Qrunfleh \& Tarafdar, 2016). Consequently, the ninth hypothesis is as follows:

H9: supply chain orientation affects supply chain agility.

\subsection{The company market orientation and the supply chain agility}

Market orientation may be a set of knowledge base activities and processes that provide customers satisfaction through continuous assessment of their desires. In general, contestant orientation isn't stressed. Corporations that might prefer to be market-oriented ought to understand their customers' current and future desires, in order that they will add worth to them. Corporations ought to establish and satisfy their customers' needs; staff in market oriented organizations pay much attention to the standard of services that they supply. Also, the staffs of such organizations pay a 
good deal of your time with their customers. Changing into market orientation and staying market orientation square measure essential for the success of corporations (Rajoii, 2009). Underneath bound environmental conditions, market orientation could have a touch result on the company's performance and be additional powerful beneath different environmental conditions. Corporations with market-oriented behaviors contemplate requirement expressed by customers within the market and check out to form merchandise and supply services which will meet those needs. Market-oriented corporations increase their awareness of their clients' desires and desires by evaluating them and might offer new merchandise and services in line with the market and therefore the customer. Hence, the requirement to new approaches is felt, agility being one. During this method, one among the foremost necessary factors in winning the competition is that the promotion of offer chain legerity. An industrial organization is competitive that has powerful and competitive elements and agility along. That is, the corporate supply chain should have competitive suppliers with globally competitive capabilities and additionally a series with agility ideas. (Qrunfleh \& Tarafdar, 2013). Consequently, the tenth hypothesis is as follows:

H10: The Company's market orientation affects the supply chain agility.

According to the presented models as above, the conceptual model of this research was developed as follows (Fig. 1).

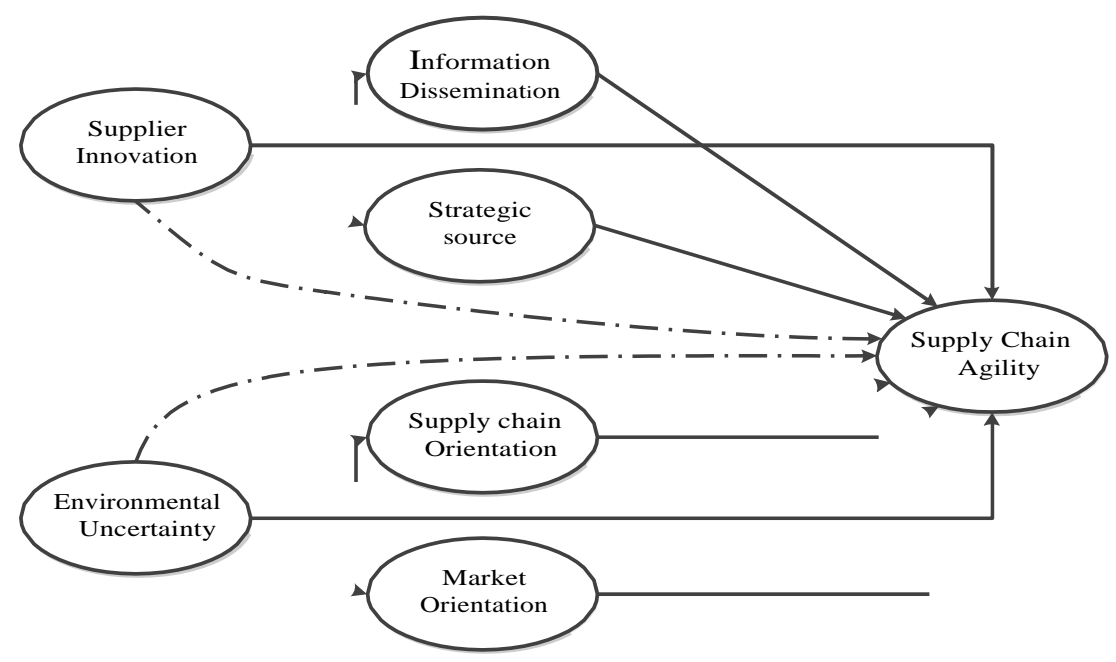

Fig. 1: Conceptual model

\section{Research Methodology}

The purpose of this analysis is to use its results to boost the amount of provide chain lightsomeness of automobile firms and is descriptive and correlation kind in terms of the analysis technique. During this analysis, the statistical population consisted of 
515 managers of components suppliers of SGSC. During this analysis, the Cochran formula was wont to confirm the sample size. Therefore, 220 managers' components suppliers of SGSC (by sampling method) were selected. During this study, 250 things were distributed and 228 final questionnaires were collected and information was analyzed based on them. The initial information of this analysis was compiled by the researcher created form adapted from Kim and Chai (2017) and Gligur et al. (2016) models.

Convergent Validity: during this study, the oblique validity was accustomed confirm the validity that is one in all the vital criteria in determining the work of measure models; it examines the correlation of every structure with paper queries (index). an AVE slightly below 0.50 may well be acceptable in an exceedingly very "interesting" if it doesn't turn out major discriminant validity issues the diminished AVE is noted and mentioned within the Limitations any important effects involving the low AVE LV's control to the next significance demand (e.g., $|\mathrm{t}|>=2.2$ instead of $|\mathrm{t}|>=2.0$ ), and 4) any discussion of interpretation, and particularly implications, involving the low AVE LV's are clearly labeled as "very provisional" and in would like of replication..

Reliability: In this study, Cronbach's Alpha coefficient was used to determine the reliability. Convergent validity and Cronbach's Alpha results are presented in table (1).

Table 1: Convergent validity and Cronbach's alpha coefficient

\begin{tabular}{ccc}
\hline Variables & Cronbach's Alpha & AVE \\
\hline Supply chain orientation & 0.782 & 0.663 \\
\hline Production of information & 0.882 & 0.685 \\
\hline Information dissemination & 0.726 & 0.722 \\
\hline Response to the information & 0.774 & 0.804 \\
\hline Environmental uncertainty & 0.769 & 0.839 \\
\hline Company Supply Chain Agility & 0.733 & 0.556 \\
\hline Supplier innovation & 0.798 & 0.637 \\
\hline $\begin{array}{c}\text { Green supply chain sharing } \\
\text { information }\end{array}$ & 0.772 & 0.728 \\
\hline Strategic resources & 0.786 & 0.593
\end{tabular}

According to Table (1), the reliability of the tool has been approved, and the convergent validity is confirmed by a value higher than 0.5 . In this research, correlation test and structural equation modeling (SEM) tests were used to analyze the data by LISREL software. In addition, it is important to examine direct effects as compared with indirect effects, which the VAF 1 test was examined for this 
purpose. To determine the intensity of the indirect effect by an intermediate variable, VAF was employed. Using this criterion, the ratio of indirect effect to total effect is calculated. The amount of VAF is calculated from the equation 1:

$$
V A F=\frac{a^{\prime} b}{(a ? b) \quad c}
$$

Formula Assumptions:

A: The value of the path coefficient between the independent variable and the mediator. B: The value of the path coefficient between the mediator and dependent variables.

C: The value of the path coefficient between independent and dependent variables.

\section{Findings}

The results of the descriptive analysis of the variables and the KolmogorovSmirnov test are presented in Table (2)

Table 2: Descriptive analysis of research variables $(n=228)$

\begin{tabular}{cccccc}
\hline & Mean & $\begin{array}{c}\text { Standard } \\
\text { Deviation }\end{array}$ & Minimum & Maximum & KS \\
\hline Supply chain orientation & 3.345 & 0.754 & 1.091 & 5.000 & 0.000 \\
\hline $\begin{array}{c}\text { Information production (market } \\
\text { orientation) }\end{array}$ & 3.313 & 0.827 & 1.000 & 5.000 & 0.000 \\
\hline $\begin{array}{c}\text { Information dissemination } \\
\text { (market orientation) }\end{array}$ & 3.633 & 0.837 & 1.000 & 5.000 & 0.000 \\
\hline $\begin{array}{c}\text { Response to information } \\
\text { (market orientation) }\end{array}$ & 3.471 & 0.870 & 1.000 & 5.000 & 0.000 \\
\hline $\begin{array}{c}\text { Environmental uncertainty } \\
\text { Company Supply Chain Agility }\end{array}$ & 3.305 & 0.860 & 1.000 & 5.000 & 0.000 \\
\hline $\begin{array}{c}\text { Supplier innovation } \\
\text { Green supply chain sharing } \\
\text { information }\end{array}$ & 3.528 & 0.631 & 1.714 & 5.000 & 0.009 \\
\hline Strategic resources & 3.283 & 0.874 & 1.875 & 5.000 & 0.007 \\
\hline
\end{tabular}

Descriptive analysis results confirm the appropriateness of supply chain agility and the set of factors that affect it. The value is larger than the mean (3) in all variables (considering the use of the Likert spectrum in this research, the numerical value of 3 is considered as a standard or mean value in the range of 1 to 5). As shown in Table (2), the level of significance of the test is less than the mean value of 0.05 ( $\mathrm{p}<0.05)$. Therefore, nonparametric tests were used. The results of the 
correlation coefficient between the variables of the model are reported in Table (3).

Table 3: Correlation coefficients between variables

\begin{tabular}{|c|c|c|c|c|c|c|c|c|c|}
\hline Variables & 1 & 2 & 3 & 4 & 5 & 6 & 7 & 8 & 9 \\
\hline Supply chain orientation & 1 & & & & & & & & \\
\hline $\begin{array}{c}\text { Information production } \\
\text { (market orientation) }\end{array}$ & $.685^{* *}$ & 1 & & & & & & & \\
\hline $\begin{array}{c}\text { Information dissemination } \\
\text { (market orientation) }\end{array}$ & $.604 * *$ & $.679 * *$ & 1 & & & & & & \\
\hline $\begin{array}{l}\text { Response to information } \\
\text { (market orientation) }\end{array}$ & $.640 * *$ & $.593 * *$ & $.692 * *$ & 1 & & & & & \\
\hline Environmental uncertainty & $.698 * *$ & $.841 * *$ & $.653 * *$ & $.691 * *$ & 1 & & & & \\
\hline $\begin{array}{c}\text { Company } \text { Supply Chain } \\
\text { Agility }\end{array}$ & $.639 * *$ & $.754 * *$ & $.699 * *$ & $.676^{* *}$ & $.740 * *$ & 1 & & & \\
\hline Supplier innovation & $.590 * *$ & $.563 * *$ & $.438 * *$ & $.518 * *$ & $.554 * *$ & $.597 * *$ & 1 & & \\
\hline $\begin{array}{c}\text { Green supply chain sharing } \\
\text { information }\end{array}$ & $.672 * *$ & $.680 * *$ & $.658 * *$ & $.687 * *$ & $.752 * *$ & $.750 * *$ & $.750 * *$ & 1 & \\
\hline Strategic resources & $.705 * *$ & $.643 * *$ & $.589 * *$ & $.694 * *$ & $.614 * *$ & $.701 * *$ & $.508 * *$ & $.605^{* *}$ & 1 \\
\hline
\end{tabular}

Considering the significance level of the test, it is determined that there is a significant relationship between the model variables $(\mathrm{P}<0.01)$. Results show that there is a significant positive correlation between the variables. In the following, structural equation modeling was used to answer the research hypotheses. Accordingly, in the first step, the factor loadings were studied and the structural research model was investigated. The results of factor loadings and significant numbers are presented in Table (4).

Table 4: Factor loadings and significant numbers for each research structure

\begin{tabular}{cccc}
\hline Variables & $\begin{array}{c}\text { Number of } \\
\text { items }\end{array}$ & $\begin{array}{c}\text { value of Factor } \\
\text { loading }\end{array}$ & $\begin{array}{c}\text { The value of the significant } \\
\text { coefficient }\end{array}$ \\
\hline Supplier innovation & 8 & $0.807-.0328$ & $2.135-19.438$ \\
\hline Environmental uncertainty & 4 & $0.768-0.817$ & $14.190-20.315$ \\
\hline Strategic resources & 5 & $0.731-0.864$ & $11.587-39.284$ \\
\hline Information sharing & 11 & $0.345-0.762$ & $2.588-15.485$ \\
\hline Supply chain orientation & 11 & $0.587-0.831$ & $7.932-22.206$ \\
\hline The market orientation & 3 & $0.871-0.894$ & $28.342-42.756$ \\
\hline Supply Chain Agility & 14 & $0.511-0.895$ & $3.600-45.03$ \\
\hline
\end{tabular}

According to the results presented in Table (4), in all cases, the coefficients of the factor loadings are greater than 0.4 which indicates the suitable fit of the measuring models. Also, significant coefficients with a value above 1.96 confirmed the significance of factor loadings' coefficients. The findings confirm that all structures of this study have been well- fitted. Accordingly, in the following, a 
structural model is studied in which the coefficients are determined and the path coefficients are presented (Fig. 2).For this part of research, we used LISREL9 to run the model.

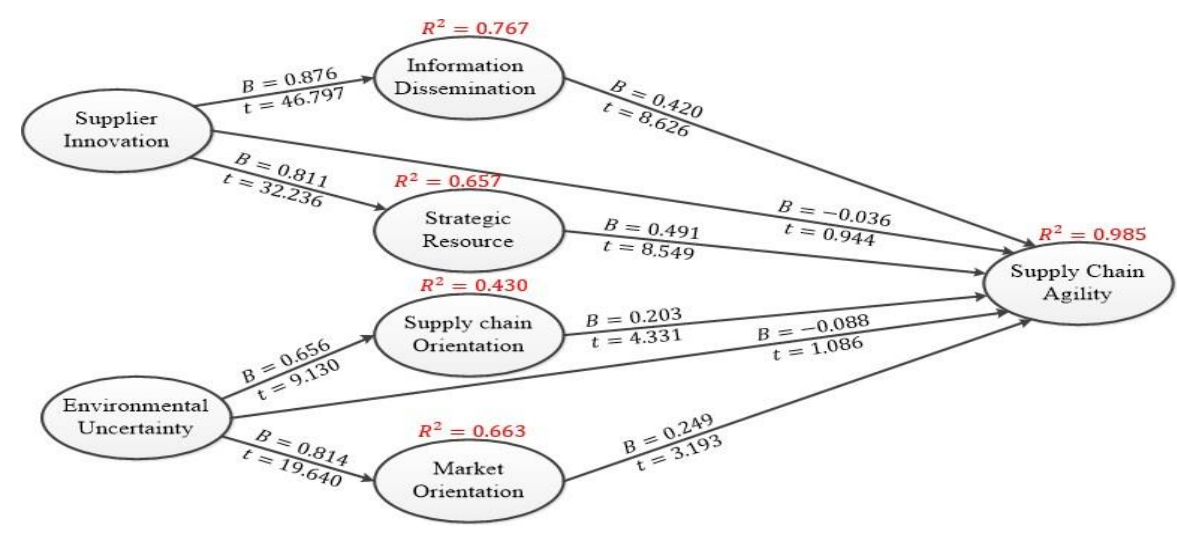

Fig. 2: Model of the research, along with regression and t-value coefficients

According to Figure 2, the trail coefficients between the most ways within the gift analysis area unit mapped in accordance with the abstract model of the analysis. The findings show that in most of the present ways, the regression coefficient is beyond 0.4 that indicates the quality of the variables' influence. (In this case, only 2 ways have a value but 0.4).However, the study of great numbers indicates that regression coefficients are statistically significant $(p>1.96)$ altogether ways. The results of the analysis show that everyone hypotheses are validated.

In addition, the determination coefficients also are conferred inside the variables affected by different variables. During this regard, in step with Fig. 2, it will be all over that the set of things that influenced the agility of the availability chain during this model will account for ninety eight of the variations. Given the worth of the constant of determination that is larger than 0.33 , the fitting of the model conferred during this study is confirmed. It will be declared that, the importance constant $o$ larger than 1.96 has been observed in all ways of the theoretical model that confirms the importance of regression coefficients effects. Indirect effects are measured by victimization the VAF technique.

The indirect effect of supplier innovation with agility

\section{A) With the mediating variable of information sharing}

The findings confirm that information sharing plays an appropriate mediator role $(\mathrm{VAF}>0.5)$ in the relationship of supplier innovation and supply chain agility.

$$
V A F=\frac{0.811^{\prime} 0.491}{(0.811 ? 0.491) 0.036}=0.931
$$




$$
V A F=\frac{0.876^{\prime} 0.420}{(0.876 ? 0.420) 0.036}=0.910
$$

\section{B) With the mediating variable of strategic resources}

The findings confirm that strategic resources play an appropriate mediator role (VAF> 0.5) in the relationship of supplier innovation and supply chain agility.

The indirect effect of environmental uncertainty with agility.

$$
V A F=\frac{0.656^{\prime} 0.203}{(0.656 ? 0.203) 0.088}=0.652
$$

\section{C) With the mediating variable of supply chain orientation}

$$
V A F=\frac{0.656^{\prime} 0.203}{(0.656 ? 0.203) 0.088}=0.652
$$

The findings confirm that supply chain orientation play an appropriate mediator role (VAF> 0.5) in the relationship of environmental uncertainty and supply chain agility.

\section{D) With a market-oriented mediating variable}

$$
V A F=\frac{0.814^{\prime} 0.249}{(0.814 ? 0.249) 0.088}=0.697
$$

The findings confirm that market orientation play an appropriate mediator role (VAF> 0.5) in the relationship of environmental uncertainty and supply chain agility.

\section{Discussion}

The main hypothesis during this study was that supplier innovation and environmental uncertainty have an effect on supply chain gracefulness through info sharing, strategic resources, supply chain orientation and market orientation. The findings of this study have totally confirmed this one. The findings of this study square measure in accordance with the results obtained from Kim and Chai (2017) and Gligor et al. (2016). It will be declared that info sharing, strategic resources, provide chain orientation and market orientation play a vital role within the relationship of supplier innovation and environmental uncertainty with supply chain agility. Within the following, all hypotheses derived from this hypothesis square measure mentioned and compared. In the first hypothesis, the positive impact of provider innovation on the gracefulness of the provider was confirmed. This means that the suppliers who enforced innovation within their works have reached to agility in the company. During this regard, particle and Jane (2014) investigated the consequences of two organizational variables (market orientation and structure innovation) on provide chain agility. Their results indicated that firms with high market orientation and innovation have a lot of agile supply chains, that square measure per the results obtained during this study. Conjointly results of Kim and 
Chai (2017) and Golavar (2015) studies are in line with the results of this hypothesis.

Accordingly, Golavar (2015) has argued that the globe and later on the management practices are ever-changing and to reach a unique world, there ought to be a unique management. gracefulness is one of the necessary factors that allows the manager to modify changes a lot of properly, quicker and a lot of effectively, utilize the potential opportunities created by the amendment within the best method, work to enhance the organization and to fulfill the goals and future desires of the organization and conjointly introduce high-quality merchandise and services in a very comparatively short amount of your time, produce competition and some quite market differentiation from a variety of aspects like price, quality, delivery time, flexibility, fast response. During this regard, innovative suppliers will have an impact on gracefulness.

The impact of supplier innovation on info sharing was studied during this hypothesis and therefore the results indicate that provider innovation includes a positive and important impact on info sharing. The results of this study will be compared with the results of Gligur et al. (2016) that rumored similar results. Also, Prajogo and Olhager (2012) and Frazier et al. (2009) studied the impact of supplier innovation on info sharing, and terminated that the supplier's innovation includes a positive and important impact on info sharing that is per our results. Prajogo and Olhager (2012) argued that in organizations that take pleasure in provider innovation and data sharing between the supplier and alternative elements of the supply, long-run relationships with the chain partners square measure inspired through social norms and trust rather than legal and inflexible contracts, and in such organizations, sharing are going to be of nice importance as a mechanism to make coordination and cooperation with supply chain partners. Kim and Chai (2017) believe that provider innovation helps makers scale back their latency to promote changes. In fact, supplier innovation includes a positive impact on promoting info sharing and permits the organization to be a lot of tuned in to client demand.

The results of third hypothesis conjointly showed that provider innovation includes a positive and important impact on strategic resources. As supplier innovation will have an effect on the strategic supply chain resources. During this regard, Oke et al. (2013) in a very analysis that was supported the impact of supplier innovation on strategic resources declared that the tendency to pioneer within the supplier effect on higher cognitive process regarding supply chain strategic resources. Conjointly the findings of Kibbeling et al. (2013) and Myreen (2010) square measure per the results obtained during this study.

To illustrate, Kibbeling et al. (2013) argue that innovation makes suppliers have nice attention in provision of primary resources; so, the getting and procural strategy is of nice importance and cases like timely delivery of raw materials, 
reducing the retardation of fast technological changes, enough material transportation, enough inventory and price savings square measure the characteristics of supplier innovation. Within the fourth hypothesis, the impact information sharing on provide chain gracefulness studied and therefore the results showed that information sharing includes a positive impact on supply chain gracefulness. In alternative words, firms that share info can produce gracefulness within the supply chain. In line with the findings of this study, Huanga et al. (2012) and Swafford et al. (2008) pointed to the positive impact of knowledge sharing on supply chain agility. Also, Kazazi et al. (2010) rumored similar and consistent results with these results.

Huanga et al., (2012) argued that organizations ought to try and save their time, cash and gracefulness by making direct channels of receiving info between the sales centers and therefore the office, establishing associate degree electronic portal to get info regarding client orders and dominant daily sales, creating affiliation between the provision department and therefore the development department, coordinative between sales and operation departments, and therefore the most significantly sharing the data. consistent with Kzazi et al. (2010), establishing a shared data system between the corporate and suppliers, sharing info between completely different units, business and electronic procural development within the supply chain, and applying AI in higher cognitive process square measure the capabilities of knowledge technology to realize gracefulness. Findings of the fifth hypothesis indicated that strategic resources have a positive and important impact on supply chain agility. So, if firms operate strategically in their resources, their provide chain agility also rises. During this regard, Kim and Chai (2017) recognized a major relationship between strategic resources and supply chain agility that is per the results obtained during this study. conjointly from alternative studies that square measure per the results obtained during this study we are able to consult with the study by Monczka et al. (2015) and Wang (2010); Baghebani (2011). They have rumored a major relationship between strategic sources and supply chain agility in their study.

According to Monczka et al., (2015), one among the areas wherever managers have targeted a lot of is getting and resourcing management. Within the last decade, getting management within the provide chain has been a challenge for major firms, and achieving a world competitive level in supply has become a serious would like. Therefore, firms should rigorously review their getting strategy to hide environmental turbulence. Additionally, firms should listen to the very fact that selecting a method can have an effect on market competition (Monczka et al., 2015) .Also consistent with Baghebani (2011), with the growing importance of supply chain agility, shopping for patterns have a central role which will boost a corporation from a temporary purchaser to a strategic partner. Having a getting strategy may also be effective in increasing the provision management capabilities. 
With respect to the importance and enlargement of supply chain agility in organizations, the importance of targeting the purchases has conjointly doubled. The impact of up the performance of those 2 sections is visible on the performance of the organization in a very sort of ways that, like reducing inventory, increasing sales, decreasing client waiting time and plenty of alternative things that ultimately result in improve company performance.

The impact of uncertainty on supply chain agility was projected because the sixth hypothesis during this study .In this regard, Kim and Chai (2017) declared that uncertainty includes a positive and important impact on provide chain agility that is per the results of this study. The study by Glilgur et al. (2013) conjointly showed similar ends up in line with these results. Also, similar results were obtained within the study of Nasrallahi et al. (1395). so as to additional clarify, Gligour et al. (2013) declared that the changes of social factors that emerge to guard surroundings, labor productivity expectations and legal pressures are essential to survival of a corporation, attract enough customers to make a positive and profitable income, which needs a fast response to changes or alleged agility in an environment with uncertainty. The requirements of organizations that might wish to respond a lot of quickly to the needs of their customers, the changing surroundings of competition and therefore the increasing complexness of the surroundings have led to the emergence of agility.

The findings of this hypothesis showed that uncertainty features a positive and vital result on supply chain orientation. This suggests that managers who observe uncertainty have a lot of thriving offer chain orientation. During this regard, the results of Gilgor et al. (2016) are in keeping with these results. Naini et al. (2011) conjointly observed similar and consistent results and argued that uncertainty has positive and vital relationship with supply chain orientation. During this regard, Adabi (2014) suggests that increase a sequence and attempting to extend the advantages of the whole supply chain square measure essential to survival and success of the present markets. Makers, suppliers, distributors, warehouses, retailers and customers have tried to insure themselves in world markets through building a network of organizations and activities within the type of a supply chain. That is, organizations work along to realize common goals, they need associate degree best supply chain orientation, and therefore the edges aren't shared among the members of the chain in order that every part of the chain simply seeks to extend its profit. This can be achieved once the members of the chain can build the required coordination. During this case, the sole hypothesis for chain success is provided, however it's not enough to ensure it. As a result of the present markets are speedily developing and every chain has robust competitors that increase choices for purchasers, every chain has many choices to settle on its members and facilities. It conjointly desires the foremost acceptable choice to succeed and to own a lot of competitive benefits over its competitors. During this hypothesis, the results 
indicate that uncertainty incorporates a positive and vital result on the firm's market orientation. In different words, it had been found that corporations with uncertainty have a positive result on their market orientation. During this regard, the findings of Kim and Chai, (2017), Gligor et al. (2016), Kumar et al. (2011) studies is in keeping with the results of this study that indicate uncertainty has positive result on company's market orientation.

To additional perceive this hypothesis, Narver associate degreed slater (2000) believe that atmosphere during which trendy corporations are situated is an environment of quality and uncertainty. Customers square measure more and more pushing corporations to provide higher product and services should place their customers and therefore their desires and desires at the middle of their business and a focus so as to achieve competitive advantage and success during this turbulent atmosphere as a result of these days business atmosphere is heavily influenced by the competition between companies and therefore the fast technological modifications and the continuous change within the demands and desires of consumers. The market-oriented approach contributes to the important implementation of this idea. Therefore, it will be aforesaid that market orientation lies within the idea of promoting. Market orientation worries as a result of with increasing competition among makers, uncertainty rises, and therefore the market orientation puts customers at the middle of attention and seeks to make a superior price for them. The market orientation considers to make a superior price for purchasers, competitors and their strengths and weaknesses furthermore as intertasking coordination. Market-oriented corporations have a competitive advantage in responding quickly to the requirements of the market and customers in today's turbulent market. Also, the on top of mentioned hypothesis explicit that the provision chain orientation incorporates a positive and vital result on the provision chain agility. consequently, Mehrabani and Hassanzadeh (1394); Gligor et al. (2016) and Naini et al. (2015) are in keeping with the results of this analysis.They have reportable a positive relationship between offer chain orientation and supply chain agility in their studies.

Mehrabani and Hasanzadeh (2015) explicit that: Companies should pay a great deal of attention to supply chain orientation so as to manage the connection with the most supplier, as a result of this can result in produce relationship management with the most provider and conjointly corporations gain higher performance outcomes and expand chain read by making a supply chain orientation. Gligor et al. (2016) conjointly argued supply chain orientation will improve strategic resources and company competition and probably ends up in rising gracefulness of the company's supply chain. The tenth and therefore the last hypothesis during this study were to look at the result of company's market orientation on supply chain agility. The results showed that market orientation incorporates a vital result on supply chain agility. Kim et al. (2017) showed similar results. Qrunfleh and Tarafdar (2013) and 
Rajavi (2009) were in keeping with these results.

Qrunfleh, and Tarafdar (2013) have explicit that underneath sure environmental conditions, market orientation could have a bit result on the company's performance and be a lot of influential underneath different environmental conditions. Corporations with market-oriented behaviors contemplate the desires the requirements the wants \} expressed by customers within the market and check out to create product and supply services which will meet those needs. Market-oriented corporations increase their awareness of their clients' desires and desires by evaluating them and may give new product and services in line with the market and therefore the customer. Thus, the necessity to new approaches is felt, agility being one. During this approach, one amongst the foremost vital factors in winning the competition is that the promotion of offer chain agility. Once associate degree industrial organization is competitive that has powerful and competitive parts and agility along. That is, the corporate supply chain should have competitive suppliers with globally competitive capabilities and also a sequence with agility ideas.

\section{Suggestion for Future Research}

We suggest for future studies to focus on the uncertainty in the closed loop supply chain or the le-agile are more extensive studies and the innovation factor is considered as an independent variable to know how it can be increased performance of SCM. On the other hand, we suggest considering the role of flexibility of innovation in forward and reverse supply chain.

\section{References}

Adabi, F. (1393). A Mathematical Model to Design Supply Chain Network with Efficient Facility in Uncertainty, Faculty of Industrial Engineering. Urmia University of Technology.

Azar, A., Tizro, A., \& Abbas Moghbel B. (2010). Designing a Supply Chain Agility Model; Interpretative-Structural Modeling Approach. Professor of Human SciencesManagement Researches in Iran, 14(4), 1-25.

Abdi, M. R., Edalat, F. D., \& Abumusa, S. (2017). Lean and Agile Supply Chain Management: A Case of ITS Distribution Industry in the Middle East. In Green and Lean Management. Springer International Publishing, 37-69

Ajibolade, S. O., Arowomole, S. S. A., \& Ojikutu, R. K. (2010). Management accounting systems, perceived environmental uncertainty and companies 'performance in Nigeria. International Journal of Academic Research, 2(1), 228244.

Baghebani, M. (1390). The Relationship between Purchasing Strategy, Supply Chain Management and Financial Performance of the Company (Case Study of 
Goldiran Co), Master's thesis, Payame Noor University, Faculty of Management, Economics and Accounting).

Chegeni, A., Kamranvand, S., \& Zahraee, S. M. (2016). A Relational Study of Supply Chain Agility and Firms' Performance in the Services Providers.

International Review of Management and Marketing, 6(4S), 38-42.

Chen, C. J., \& Wu, J. C. (2015). Supply Chain Agility and Innovation: The Relationships among it Integration, Trust, And Competitive Advantage. In Managing Intellectual Capital and Innovation for Sustainable and Inclusive Society: Managing Intellectual Capital and Innovation; Proceedings of the MakeLearn and TIIM Joint International Conference 2015. ToKnowPress.

Chiang, C.-Y., Kocabasoglu-Hillmer, C., \& Suresh, N.C., (2012). An empirical investigation of the impact of strategic sourcing and flexibility on firm's supply chain agility. Int. J. Oper. Prod. Manag. 32 (1), 49-78.

Esper, T. L., Ellinger, A. E., Stank, T. P., Flint, D. J., \& Moon, M. (2010). Demand and supply integration: A conceptual framework of value creation through knowledge management. Journal of the Academy of Marketing Science, 38(1), 5-18.

Fernando, Y., (2017). Green supply chain agility in EMS ISO 14001 manufacturing firms: empirical justification of social and environmental performance as an organizational outcome. International Journal of Procurement Management, 10(1), 51-69.

Frazier, G. L., Maltz, E., Antia, K. D., \& Rindfleisch, A. (2009). Distributor sharing of strategic information with suppliers. Journal of Marketing, 73(4), 31-43.

Fakhrzad, M.B. Pourfereidouni, Hojjat, \& Pourfereidouni Mitra. (2018). Dualchannel Supply Chain Synchronization with Deterministic and Stochastic Demand under Cost-sharing Contract. International Journal of Supply and Operations Management (IJSOM), 5(1), 28-41.

Golavar, Z.(2015).The Impact of Agile Production on the Supply Chain, International Conference on Modern Research in Management. Economics and Accounting.

Gebrekidans, D. A. (2016). Achieving supply chain agility through innovation capability building. International Journal of Supply Chain and Operations Resilience, 2(2), 114-143.

Gligor, D. M. (2013). The concept of supply chain agility: Conceptualization, antecedents, and the impact on firm performance. 
Gligor, D. M., Holcomb, M. C., \& Feizabadi, J. (2016). An exploration of the strategic antecedents of firm supply chain agility: The role of a firm's orientations. International Journal of Production Economics, 179, 24-34.

Gligor, D. M., Holcomb, M. C., \& Stank, T. P. (2013). A multidisciplinary approach to supply chain agility: Conceptualization and scale development. Journal of Business Logistics, 34(2), 94-108.

Gordon LA, Narayanan VK. (2007). Management accounting systems, perceived environmental uncertainty and organizational structure: an empirical investigation. Accounting. Organizations \& Society, 9 (1), 33-47.

Huanga P., Ouyangb T.H., Panc Sh., Choudthe T. (2012) Role of IT In Achieving Operational Agility: A Case Study Of Haier, China. International Journal of Information Management, 32, 294- 298.

Harbi,salim. Bahroun, Mohamed. Bouchriha, Hanen. (2018). How to Estimate the Supplier Fill Rate When the Supply Order and the Supply Lead-time Are Uncertain? International Journal of Supply and Operations Management (IJSOM), 5(3), $197-$ 206.

Khan K, A., \& Pillania, R. K. (2008). Strategic sourcing for supply chain agility and firms' performance: A study of Indian manufacturing sector. Management Decision, 46(10), 1508-1530.

Kibbeling, M., H. der Bij, A. Weele. (2013). Market Orientation and Innovation in Supply Chains: Supplier's Impact on Customer Satisfaction. Journal of Product Innovation Management, 30(3), 500-515.

Kim, M., \& Chai, S. (2017). The impact of supplier innovation, information sharing and strategic sourcing on improving supply chain agility: Global supply chain perspective. International Journal of Production Economics, 187, 42-52.

Kocabasoglu, C., \& Suresh, N.C., (2006). Strategic sourcing: an empirical investigation of the concept and its practices in US manufacturing firms. J. Supply Chain Manag. 42 (2), 4-16.

Kumar, V., Jones, E., Venkatesan, R., \& Leone, R. P. (2011). Is market orientation a source of sustainable competitive advantage or simply the cost of competing? Journal of marketing, 75(1), 16-30.

Khodadad Hosseini H., Lashkarblaki M., \& Farrokhi F. (2012). Strategic Design Alternative Approaches in Uncertainty. Analytical-Adaptive Approach, Public Management Research, 5(18), 45-63.

Kazemzadeh, R., Eskandari H.R., \& Kakavand, V. (1392). Investigating Different Scenarios of Information Sharing in the Supply Chain Using Simulation. 
International Industrial Engineering and Production Management magazine, 12(9), 284-298.

Kazazi, A., \& Sohrabi R. (2010). Presentation of Components and Indicators of Agility Assessment of Supply Chain of National Iranian Oil Company (Case Study: Southern Oilfield Company). Change Management Research, 4, 141-165.

Jafar Nejad A., \& Darvish M. (2009). Assessment and evaluation of agility in the supply chain. A Case Study, Executive Management Research Report, and Year 9, 36 (2), 40-62.

Mehrabani. Hassanzadeh Farshband, F.F., (2015). Impact of Supply Chain Orientation on the Effectiveness of Organizational Purchases by Suppliers of BouAli Sina Petrochemical Company. Third International Accounting and Management Conference, Tehran, Hamayeshgaran Mehr Ishraq Institute.

Mandal, S. (2016). An empirical investigation on integrated logistics capabilities, supply chain agility and firm performance. International Journal of Services and Operations Management, 24(4), 504-530.

Monczka, R. M., Handfield, R. B., Giunipero, L. C., \& Patterson, J. L. (2015). Purchasing and supply chain management. Cengage Learning.

Moniruzzaman, M., Kurnia, S., Parkes, A., \& Maynard, S. B. (2016). Business Intelligence and Supply Chain Agility. Australasian Conference on Information Systems.

Murray, J. Y., GAO, G. Y., \& Kotabe, M. (2011). Market orientation and performance of export ventures: the process through marketing capabilities and competitive advantages. Journal of the Academy of Marketing Science, 39(2), 252269.

Myreen, Magnus O. (2010). Verified just-in-time compiler on x86. ACM Sigplan Notices, 45 (1), 107-118.

Naini, S. G. J., Aliahmadi, A. R., \& Jafari-Eskandari, M. (2011). Designing a mixed performance measurement system for environmental supply chain management using evolutionary game theory and balanced scorecard: A case study of an auto industry supply chain. Resources, Conservation and Recycling, 55(6), 593-603.

Narver, J. C., \& Slater, S. F. (2000). Additional thoughts on the measurement of market orientation: a comment on Deshpande and Farley. Journal of market-focused management, 2(3), 233-236.

Nasrollahi, M., Fattahy Takhtgahi, A., \& Sajjadinia, Z., (2016). The role of IT in supply chain agility and its impact on organizational performance. Second International Conference on Management, Innovation and Entrepreneurship Paradigms, Tehran, Shahid Beheshti University. 
Oke, A., D. I., \& Prajogo, J. Jayaram. (2013). Strengthening the innovation chain: The role of internal innovation climate and strategic relationships with supply chain partners. Journal of Supply Chain Management, 49(4), 43-58.

Qrunfleh, S., \& Tarafdar, M. (2013). Lean and agile supply chain strategies and supply chain responsiveness: the role of strategic supplier partnership and postponement. Supply Chain Management: An International Journal, 18(6), 571582.

Power, D., Sohal, A., \& Rahman, S. (2011). Critical success factors in agile supply chain management. Intrnational Journal of Physical Distribution \& Logistics management, 31(4). 247-273,

Prajogo, D., \& Olhager, J. (2012). Supply chain integration and performance: The effects of long-term relationships. Information technology and sharing, and logistics integration. International Journal of Production Economics, 135(1), 514522 .

Racela, O. C. (2014). Customer orientation, innovation competencies, and firm performance: A proposed conceptual model. Procedia-Social and Behavioral Sciences, 148, 16-23.

Rajoii M. (1388). Market Orientation: Theory of Concepts and Its Results in the Organization. Art Management Magazine, (3), 10-17.

Seyedhoseini, S. M., Jassbi, J., \& Pilevari, N. (2010). Application of adaptive neuro fuzzy inference system in measurement of supply chain agility: Real case study of a manufacturing company. African Journal of Business Management, 4(1), 83-96.

Sukati, I., Hamid, A. B., Baharun, R., Yusoff, R. M., \& Anuar, M. A. (2012). The effect of organizational practices on supply chain agility: An empirical investigation on Malaysia manufacturing industry. Procedia-Social and Behavioral Sciences, 40, 274-281.

Swafford, P.M., Ghosh, S. \& Murthy, M. (2008). Achieving supply chain agility through IT integration and flexibility. International Journal of Production Economics, 116, 288-297.

Tizro, A., Azar, A., Ahmadi, R., \& Rafiei, M. (2011). Providing Supply Chain Agility Model. Case Study: Zob Ahan Co. Industrial Management, 3 (7), 17-36.

Um, J. (2016). The impact of supply chain agility on business performance in a high level customization environment. Operations Management Research, 1-10.

Van Hoek, R. I. (2011). Epilogue-Moving forward with agility. International Journal of Physical Distribution \& Logistics Management, 31(4), 290 - 301. 
Wang, W. P. (2010). A fuzzy linguistic computing approach to supplier evaluation. Applied Mathematical Modelling, 34(10), 3130-3141.

Yoon, T. Y., \& Jin, B. H. (2014). The Role of Market Orientation and Organizational Innovation in Enhancing the Supply chain Agility of Korean Apparel Firms. Journal of the Operational Research Society, 38(5), 718-732.

Zhang, C., \& Li, S. (2009). Secure information sharing in internet-based supply chain management systems. Journal of Computer Information Systems, 5 (1), 18-24.

Zutshi, A., \& O'Loughlin, A. (2015). How Australian manufacturing firms perceive and understand the concepts of agility and flexibility in the supply chain.

International Journal of Operations \& Production Management, 35(2), 246-281. 